\title{
The Status and Challenges of Sustainable Intensification of Rice-Potato Systems in Southern China
}

\author{
Yao Lu' ${ }^{1} \cdot$ Philip Kear $^{1} \cdot$ Xiaoping Lu' $\cdot$ Marcel Gatto ${ }^{2}$
}

Accepted: 6 September 2021 / Published online: 30 September 2021

(c) The Author(s) 2021

\begin{abstract}
Potato is the world's largest non-cereal crop, occupying a position critical for global food security. In China, potato is the fourth largest crop adding to food security and incomes. The large population and unremitting reductions in arable land are the most critical root causes of China's food security problems. Hence, crop yield improvements and strategies to improve land use are at the forefront of solutions to increase China's food security. Maintenance of existing land resources while increasing crop yields, avoiding soil quality degradation and wastage of water are enduring problems that have long attracted widespread attention in many research fields. This article, analyzes and discusses the status and challenges to sustainable intensification of rice-potato rotation in southern China. Three significant findings were obtained in this paper, viz. availability of about 16 million hectares of suitable land for rice-potato intensification in southern China in 2016 are reported, several conservation agricultural practices with varying intensity and higher economic benefits in rice-potato rotation than rice-fallow, which may positively effects the environment. It was concluded that agricultural intensification with potato was an economically viable avenue along with good agricultural practices that minimize adverse environmental effects.
\end{abstract}

\section{Resumen}

La papa es el cultivo no cerealero más grande del mundo, ocupando una posición crítica para la seguridad alimentaria mundial. En China, la papa es el cuarto cultivo más grande que se agrega a la seguridad alimentaria y los ingresos. La gran población y las reducciones incesantes de la tierra cultivable son las causas fundamentales más críticas de los problemas de seguridad alimentaria de China. De aquí que las mejoras en el rendimiento de los cultivos y las estrategias para mejorar el uso de la tierra están a la vanguardia de las soluciones para aumentar la seguridad alimentaria de China. El mantenimiento de los recursos de tierra existentes junto con el aumento del rendimiento de los cultivos, evitando la degradación de la calidad del suelo y el desperdicio de agua, son problemas duraderos que durante mucho tiempo han atraído la atención generalizada en muchos campos de investigación. Este artículo analiza y discute el estado y los desafíos para la intensificación sostenible de la rotación de arroz y papa en el sur de China. En este documento se obtuvieron tres hallazgos significativos, a saber, se reporta la disponibilidad de aproximadamente 16 millones de hectáreas de tierra adecuada para la intensificación del arroz y la papa en el sur de China en 2016, varias prácticas agrícolas de conservación con intensidad variable y mayores beneficios económicos en la rotación de arroz y papa que en el cultivo de arroz, lo que puede tener un efecto positivo en el medio ambiente. Se concluyó que la intensificación agrícola con papa era una vía económicamente viable junto con buenas prácticas agrícolas que minimizan los efectos ambientales adversos.

Keywords Potato $\cdot$ Rice-potato rotation $\cdot$ Sustainable intensification $\cdot$ Conservation agriculture $\cdot$ Cost-benefit analysis

\section{Introduction}

Yao Lu

luyao041800@163.com

International Potato Center, Beijing, China

International Potato Center, Tu Liem, Hanoi, Vietnam
Food security is a critical and prevalent research topic globally (Lenaerts et al. 2019; Xie and Yang. 2020). Maintaining food self-sufficiency is the principle precept of China's current food security policy, which could be guaranteed if only considering the availability of cultivatable land resources 
(Fu et al. 2001; Lu et al. 2019). However, China is a densely populated country with a relatively small area of arable land. Such is the population density that China feeds almost $19 \%$ of the world's population, within its own borders, using $9 \%$ of the world's arable land (NBSPRC 2017; Shen et al. 2018). Nevertheless, due to the presence of three constraints, China's food security problems cannot be underestimated.

Firstly, the decreasing availability of arable land. Arising from China's rapid urbanization and industrialization, a loss of arable land has occurred since the 1978 market reforms and opening up to the world economy. Indeed, arable-tourban land usage is especially prominent in China's southern provinces, where these provinces occupy a larger proportion of the available arable land (Lichtenberg and Ding 2008).

Secondly, urban-bound migration away from arable centers leads to a reduction in workforce capacity reducing the optimum number of rice harvests per year. Due to the perception that food production has a relatively low benefit, large numbers of these workers have moved to nonagricultural forms of employment leading to reduced rice planting and a decline in production (Wang et al. 2018). Consequently, the loss in agricultural workers, has resulted in large areas seeing a reduction to two harvests per year between 1990 and 2015 in former triple-cropping rice land. Similarly, double-cropping areas have observed an increase in single-cropped fields annually. This overall reduction in harvests has caused increases in land underutilization or fallow fields in the winter (Huang 2009; Jiang et al. 2019).

Thirdly, soil resources are deteriorating. The long-term continuous cropping of rice and a general lack of awareness of how to maintain soil fertility (Lu et al. 2019) in China's southern provinces has caused the deterioration the soil's physical and chemical properties. Evidence from Huang (2017) indicated that these regions' soils were severely depleted, with reduced organic matter and low soil fertility. This loss in soil fertility has contributed to a decline in productivity with the potential to undermine the sustainability of agricultural production.

For many Asian smallholder farmers in developing countries, potatoes have contributed to food and nutrition security, but more recently, increasingly also serve as an important source of income (Scott 2020). Per capita potato consumption in China has doubled between 2007 and 2019, from 33.6 to $65 \mathrm{~kg}$, while, in 2019 , production peaked to some 92 million tonnes and area planted to potato recovered to some 4.9 million ha (Scott and Suarea 2012, FAOSTAT 2021). Despite China's national plan to plant 8 million ha to potato and production of 150 million tonnes in 2015 appeared too ambitious (Scott and Suarez 2012), several factors have contributed to the observed increase. For instance, China has become increasingly urbanized and affluent, consumers have paid closer attention to healthier diets, and shifting society's consumption habits towards greater food diversification (Chang et al. 2018; Jia et al. 2020). In parallel, higher income and increased urbanization have led to increased demand for processed potatoes (Devaux et al. 2020). Acknowledging the importance of potato for food security and incomes, the Chinese Ministry of Agriculture has promoted potato as a staple crop and issued formal guidelines to promote crop agro-industries (MOA 2016). Beyond national policies, regional industrial policies for have promoted the development of potato clusters, transforming rural areas and contributing to local economic development (Zhang and $\mathrm{Hu}, 2014$ ). As a result, the ricepotato rotation model in southern provinces has undergone drastic development and improvement. Recent evidence shows the economic welfare enhancing impact of potato systems in southern China on employment and income creation, and alleviating poverty ( $\mathrm{Li}$ et al. 2019; Myrick et al. 2021). Evidence of the economic welfare effects of rice-potato systems have also been documented for the Indo-Gangetic Plains (Gatto et al. 2020).

In this paper, China's capacity and potential for sustainable intensification of rice-potato agri-food systems is investigated. The following research questions for rice-potato production systems in southern China were identified:

(1) What potential area for rice-potato rotation system is available for sustainable intensification?

(2) What are the predicted/actual ecological and economic benefits of the rice-potato rotation system?

(3) What are the constraints of the rice-potato rotation system?

Data in this report was gathered using various quantitative and qualitative methods, including interviewing experts, reviewing published research on rice-potato rotation systems in rice-growing regions of southern China, and analyzing the potential growth opportunities.

\section{Background}

\section{Development and Status of Potato Production in China}

The potato crop has become a significant part of the world's food system, which is increasingly due to its growing precedence in developing countries (Devaux et al. 2020). In 2018, the global potato planting area reached 17.6 million ha, and output reached 368 million tons (FAOSTAT 2021). Globally, approximately two billion people eat potatoes as their staple food with the bulk of people living in developing countries (Devaux et al. 2020).

Despite potatoes having been cultivated in China for more than 400 years as food and as a vegetable forage (Scott and 
Table 1 Potato production and planting area in the World and China

\begin{tabular}{llrl}
\hline Category & World & China & $\begin{array}{l}\text { China's } \\
\text { propor- } \\
\text { tion }\end{array}$ \\
\hline Potato production: $10^{4} \mathrm{t}$ & 36,817 & 9024.4 & $25 \%$ \\
Potato planting area: $10^{4}$ ha & 1758 & 490.2 & $28 \%$ \\
Yield: $\mathrm{t} / \mathrm{ha}^{-1}$ & 20.94 & 18.4 & \\
\hline
\end{tabular}

Table 2 China's potato production from 2007 to 2018

\begin{tabular}{llll}
\hline Year & $\begin{array}{l}\text { Potato produc- } \\
\text { tion: } 10^{4} \mathrm{t}\end{array}$ & $\begin{array}{l}\text { Potato planting } \\
\text { area: } 10^{4} \text { ha }\end{array}$ & Yield $\left(\mathrm{kg} / \mathrm{ha}^{-1}\right)$ \\
\hline 2007 & 6479.00 & 443.03 & 14,625 \\
2008 & 7078.00 & 466.34 & 15,180 \\
2009 & 7323.00 & 508.08 & 14,415 \\
2010 & 8153.50 & 520.51 & 15,665 \\
2011 & 8829.00 & 542.40 & 16,280 \\
2012 & 8435.85 & 503.08 & 16,770 \\
2013 & 8587.95 & 502.58 & 17,090 \\
2014 & 8415.55 & 491.04 & 17,140 \\
2015 & 8226.65 & 478.56 & 17,190 \\
2016 & 8492.85 & 480.24 & 17,310 \\
2017 & 8848.15 & 485.99 & 18,205 \\
2018 & 9024.4 & 490.22 & 18,409 \\
\hline
\end{tabular}

Suarea 2012; Long et al. 2018), in 1961, China's potato output only accounted for $4.77 \%$ of global output. However, since 1990 , potato production has increased rapidly with improvements in potato breeding ( $\mathrm{Li}$ et al. 2016), production techniques and the expansion of planting areas (Yang et al. 2017). In 2018, the planting area of fresh potatoes in China reached 4.80 million ha; potato production increasing from 45.94 million tons in 1993 to 90.24 million tons in 2018, and the planting area and output accounted for $28 \%$ and $25 \%$ of the global potato planting area and output, respectively (Table 1). Since China's Ministry of Agriculture has officially recognized potatoes as a staple food, the potatoes' harvested area in China increased steadily until 2016. However, in 2016, potato production declined slightly due to biotic and abiotic factors, as shown in Table 2. At present, China's potato industry has entered a period of prosperity due to the increased area used for planting alongside stabilizing planting scale and improving potato quality (Yang et al. 2017).

China's strategies to alleviate the food security problems, caused by increased population and decreased arable land, mainly relied on increasing crop yields and land utilization rate (Xie et al. 2010). However, mitigation of the productivity gap cannot be cushioned by continued reliance on China's three major food crops because increases in rice, wheat and corn yields have limited the potential to reduce food security problems (Qu et al. 2005). Indeed, rice, wheat, and corn yields are already higher than the world average, with limited potential for further increases. Conversely, China's potato planting area is more extensive, but yields have been lower than the world average (Table 1). Hence, as a food security strategy component in China, the potato's potential yield increases remain to hold promise (Xie et al. 2010).

Besides the potential for yield increases, other agronomical characteristics favor potato as a food security crop. Agronomically, potatoes are highly adaptable, resistant to soil infertility and yield more food more rapidly on less land than any other major crop (Devaux et al. 2020). Compared with other major crops, potatoes can produce more nutritious food under less land area, harsher climate, and more arid conditions (Luo 2015). Indeed, the portion that can be consumed by humans is as high as $85 \%$ (Jin et al. 2003). Therefore, potatoes are widely planted in China's various ecological regions, especially in the impoverished western regions and remote mountainous areas. These positive attributes have played an essential role in alleviating China's food security pressure and eliminating regional poverty (Jin et al. 2003; Luo et al. 2005; Qu et al. 2005).

\section{Patterns of China's Rice-Potato Rotation Systems}

Since ancient times, Chinese agriculture has had an established tradition of intensive farming and management practices (Liu 2000). With an emphasis on increasing land utilization, this practice is referred to as cultivated land intensification. Multi-cropping of cultivated land is one of the most straightforward measures to extend cultivated land use in terms of time and space (He et al. 2016). Rice-potato rotation systems began to develop in Guangdong Province in the 1980s, mainly as a commercial spinoff to supply potatoes for Hong Kong. However, over time it gradually developed and spread to its current scale to include winter cropping areas in Guangdong, Fujian, Guangxi, and now the largest scale in low-altitude southern Yunnan. At present, about $40 \%$ of cultivated land in China has multiple cropping modes (Yan et al. 2005), and 1/4 of the food produced comes from increases in the multi-cropping index (MCI $)^{1}$ of cultivated land (Tong 1998). China mainly used crop rotation, row intercropping and relay intercropping to increase farmed land's MCI (Wen 2015). Paddy rice with subsequent dry-crop (i.e., non-paddy rice) rotation ${ }^{2}$ was one of the most dominant crop rotation methods utilized in southern China

\footnotetext{
${ }^{1}$ Multiple cropping index (MCI): Multiple cropping index refers to the period of time (usually 1 year) average number of crops planted on the same plot of arable land, that is, the average number of crops grown on arable land during the year.

2 Paddy rice and dry crop rotation: The planting methods of rice and dry crops are sequentially rotated in the same field.
} 


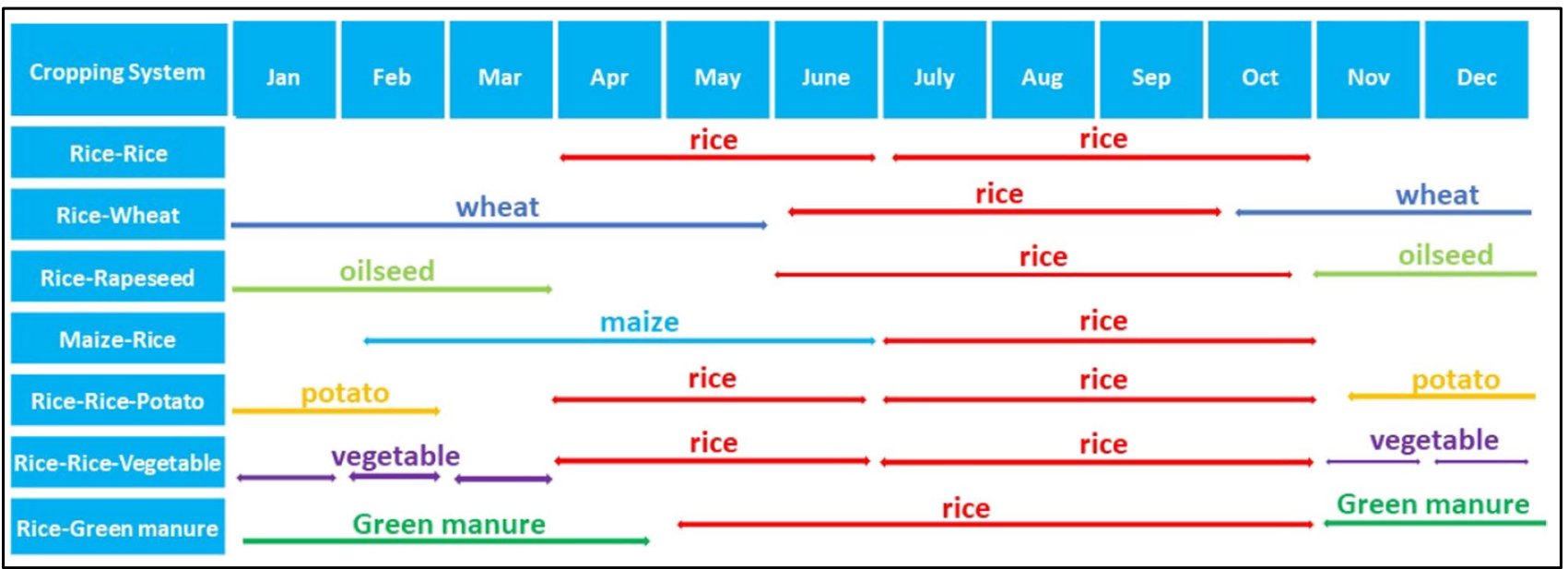

Fig. 1 Main rotation pattern with rice in the south of China

(Jiang et al. 2019). It refers to planting rice and other 'dry' crops at different periods within a single year (i.e., a single growing season) on the same field (Sun et al. 2019). This crop rotation is conducive to improving land-use efficiency, improving soil physical and chemical properties, increasing crop yields, and ensuring sustainable farmland development (Sun et al. 2019). In this way, traditional paddy-rice cropping is often followed by dry cropping of wheat, rapeseed or green manure (Fig. 1), despite minimal economic benefit (Wang et al. 2019). The southern rice areas have predominantly adopted single-crop rice or a continuous 'fallow-ricerice' cropping model (Liu and Jiang 2019). However, the 'rice-potato' cropping pattern has been widely adopted in southern winter potato planting areas in recent years (Fig. 1). This rice-potato cropping method can increase the MCI of land, increase farmers' incomes, and make full use of winter fallow fields (Jiang et al. 2019).

In the 12 rice-growing provinces of southern China, typically from late-maturing rice (150-170 days $)^{3}$ and middlematuring rice (120-150 days) $)^{2}$ harvest to the second year of rice planting, about 16 million ha rice fields are fallow (commonly referred to as winter fallow fields) (Table 4). Conditions such as temperature, light, water and fallow field soil temperature in winter and the additional 150 days of resting are conducive to winter potato production. According to Xie et al. (2010), where the potato was introduced in rotation with winter fallow paddy fields in 2006, higher yields and economic benefits of potato resulted. These trials took place across all 12 rice-growing provinces in southern

\footnotetext{
${ }^{3}$ Middle rice and late rice: in China, rice can be divided into early rice, middle rice and late rice according to seeding, growth and maturity. In general, the growing period of early rice is $90-120$ days, the middle rice is $120-150$ days, and the late rice is $150-170$ days.
}

China, with a total planting area of 642,500 ha. However, the potato planting area of winter fallow rice fields across the 12 provinces only accounted for a mere $3.93 \%$ of the total winter fallow rice fields (Xie et al. 2010). Since this planting method does not compete with rice for land, the rice-potato rotation model has excellent development potential in these areas. Indicators from Yunnan Province illustrate the potential for rapid adoption of the rice-potato model (DARAYP 2018). Between 2010 and 2017, the potato planting area (fall and winter) increased by $41.4 \%$. This figure represents an increase in land area from 153,000 ha to 217,000 ha.

\section{Sustainable and Intensive Development of Agriculture in China}

Globally, the intensification of agriculture and parallel increases in land utilization are some of the most notable changes in agriculture in the 20th Century (Matson et al. 1997; Li et al. 2004; Wang and Wang 2004). In many countries in the past 60 to 70 years, agriculture has transitioned from extensive to intensive management methods. This global trend in intensification is particularly prominent in China's agricultural sector (Xiang and Tang 2005). Agricultural intensification requires relatively high inputs (capital, labor, and technology) per unit of land area to achieve higher output and efficiency (Liu 2000). However, sustained intensification in agriculture is achievable if its impact on agroecology is limited (Ni 2018). Tilman et al. (2011) pointed out that enhancing nutrient use efficiency and reducing land reclamation are developmental pathways for sustainable agricultural intensification. Sustainable agricultural intensification focuses on the impacts and integrated benefits of ecological, economic, and social systems simultaneously. Sustainable intensification should realize food security in parallel with ecosystem conservation and farm household 
livelihood improvement (Garnett et al. 2013; Garibaldi et al. 2017). Rockstrom et al. (2017) proposed sustainable agricultural intensification within an operational framework of agricultural development, increased agricultural productivity and socio-ecological resilience geared towards protecting agro-ecologies. Given China's large population and food insecurity threat, it needed to follow a path that is both highyielding, quality-focused and efficient (i.e., intensive) while maintaining existing resources and the environment (i.e., sustainable) (Liu and Ren 1993). Thus, in short, the sustainable intensification of Chinese agriculture has been based on high yield, efficiency, quality and low resource consumption to achieve continuous productivity growth, sustained use and conservation of agriculture, natural resources, improved soil fertility and an improved rural ecological environment ( $\mathrm{Yu}$ et al. 1999).

\section{Materials and Methods}

\section{Reviewing the Publicly Available Literature}

Publicly available literature was reviewed to achieve the research objectives of this article. Information was mainly sourced from relevant documents archived under the CNKI (China National Knowledge Infrastructure, https://chn.overs ea.cnki.net/index/), including changes in the rice planting area of southern China, the paddy-dry rotation methodology, and the effects of these rotation methods on the soil. The benefits of rotation systems on the soil focused on improvements in the soil's physical and chemical properties, increases in microbial content, and fertilizer savings. At the same time, documents were collected in relation to the development potential of potato cultivation in China, and research literature on sustainable intensification, among other areas. The relevant documents are summarized in Supplementary Table 1.

\section{Data Sourcing and Processing}

The planting area and output data of food crops (including rice and potato) were derived from agricultural statistics for China, between 2007 and 2017. The yield per unit area was obtained by using yield data for grain crops and area sown. Since available statistics only correspond to Mainland China, data for Taiwan, Hong Kong and Macau were not considered in this study. Furthermore, in published national statistics, potato planting in Beijing, Tianjin, Shanghai, Jiangsu, Shandong, and Henan were included in the vegetable area instead of grain-related areas. Hence, this study also included data related to potatoes in these areas. Estimates of the potato and rice planting areas and production changes data from 12 provinces in southern China from 2007 to 2017, and
Table 3 The number of interviewees by profession

\begin{tabular}{ll}
\hline Profession & $\begin{array}{l}\text { Number of } \\
\text { interview- } \\
\text { ees }\end{array}$ \\
\hline Breeder & 8 \\
Agronomist & 4 \\
Potato pathologist & 11 \\
Farmer & 1 \\
Agricultural economist & 1 \\
Entrepreneurs & 5 \\
Total & 30 \\
\hline
\end{tabular}

individually for Yunnan, Sichuan and Guangdong in 2017 were performed using Microsoft Excel. These estimates also included calculating the ratio of total planting area to yield from available data.

\section{Key Information Interview}

Expert opinions in our research area were used to understand first-hand information and experiences. In this study, experts in potato research were consulted, which included breeders, agronomists, agricultural economists, and potato pathologists (Table 3). To better understand potato cultivation in relevant provinces, experts were interviewed in Guangdong, Sichuan and Yunnan. These interviews provided a profound understanding of the rice and dry crop rotation methods in these three provinces and the sustainable intensification in cultivation methods of rice and potato rotation.

\section{Study Area}

We selected the Provinces of Guangdong, Yunnan, and Sichuan as objects for this study. There were three prominent reasons for choosing these three provinces for this study: firstly, in 2017, their combined potato planting area accounted for about $30 \%$ of the country's total cropping area (Fig. 2), otherwise accounting for about $26 \%$ of the annual output (Fig. 3). Accordingly, these quantities illustrated the importance of potatoes in these areas. Secondly, all three provinces performed winter potato cropping. The main winter potato planting regions are Dehong, Puer and Lincang in Yunnan province, Chengdu and Liangshan in Sichuan province, Shanwei and Huizhou in Guangdong province. Winter cropping was primarily observed in Guangdong Province, where winter potatoes utilize $85 \%$ of the area, and $15 \%$ were spring potatoes. Lastly, the rice-rice-potato rotation system is very mature in Guangdong Province, and Yunnan Province had become the country's largest winter potato production area since 2017 , indicating that the potato industry in this region 


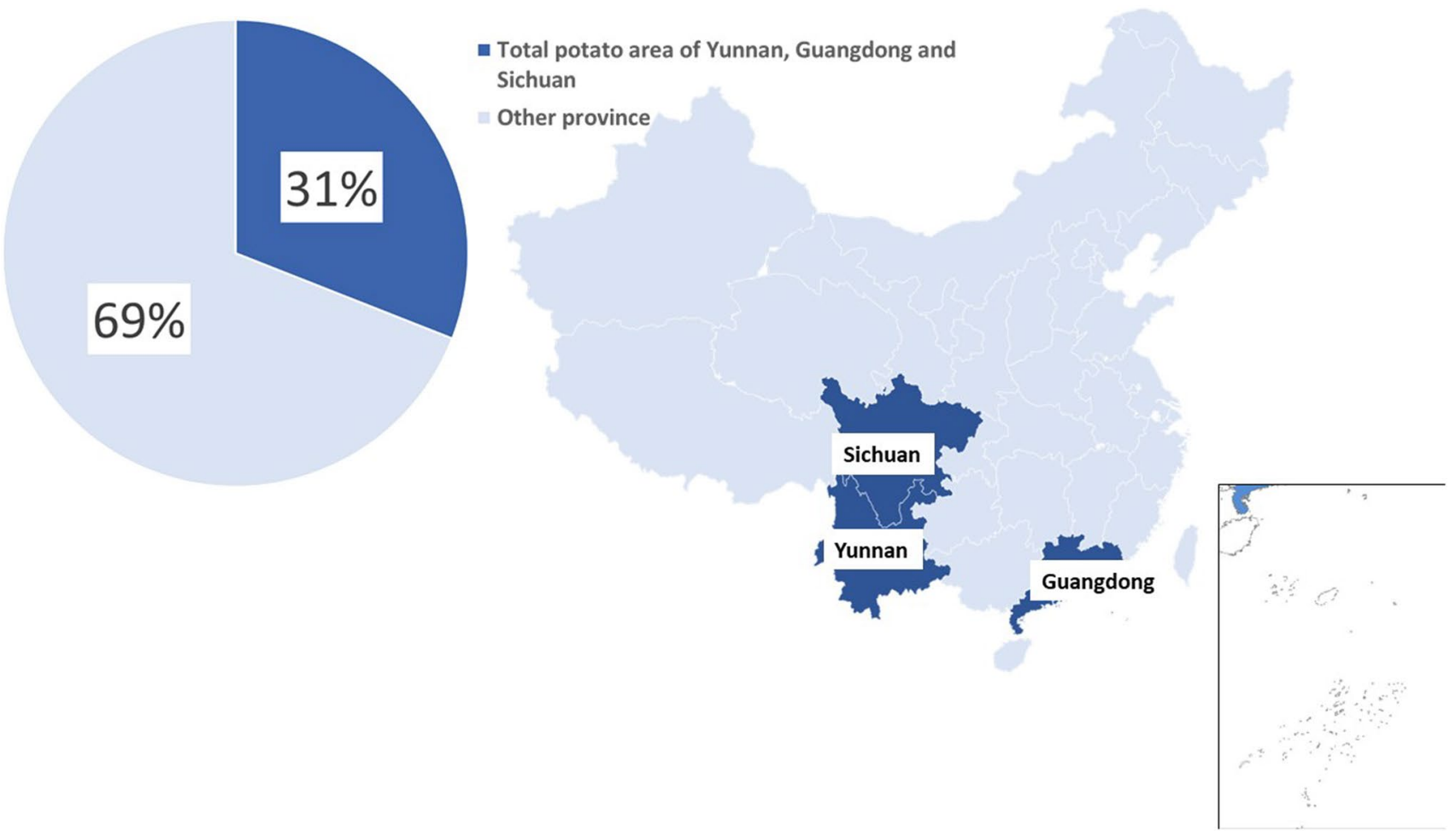

Fig. 2 Proportion of potato planting area in Yunnan, Sichuan and Guangdong provinces to the total potato planting area in China

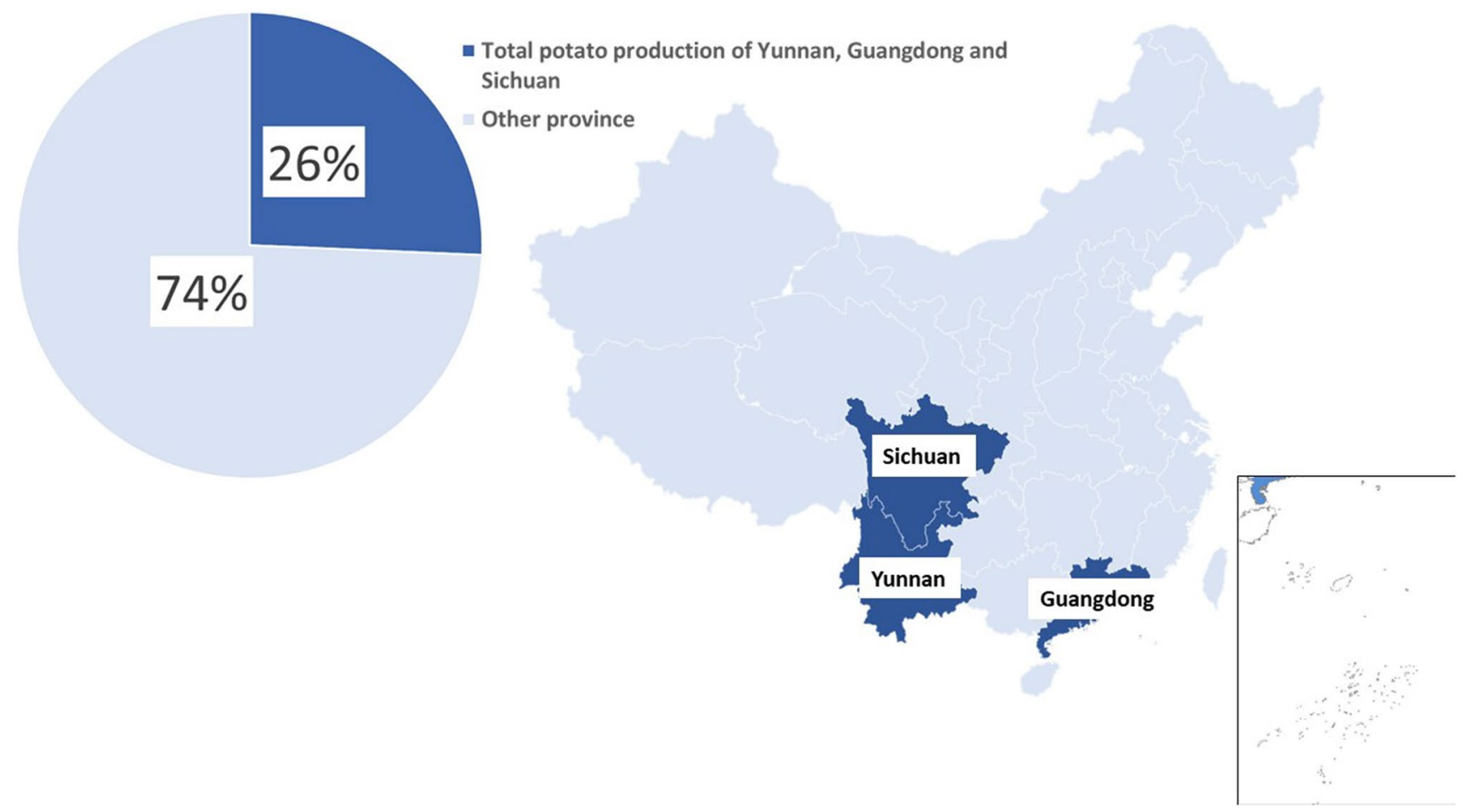

Fig. 3 Proportion of potato production in Yunnan, Sichuan and Guangdong provinces to the total potato production in China 


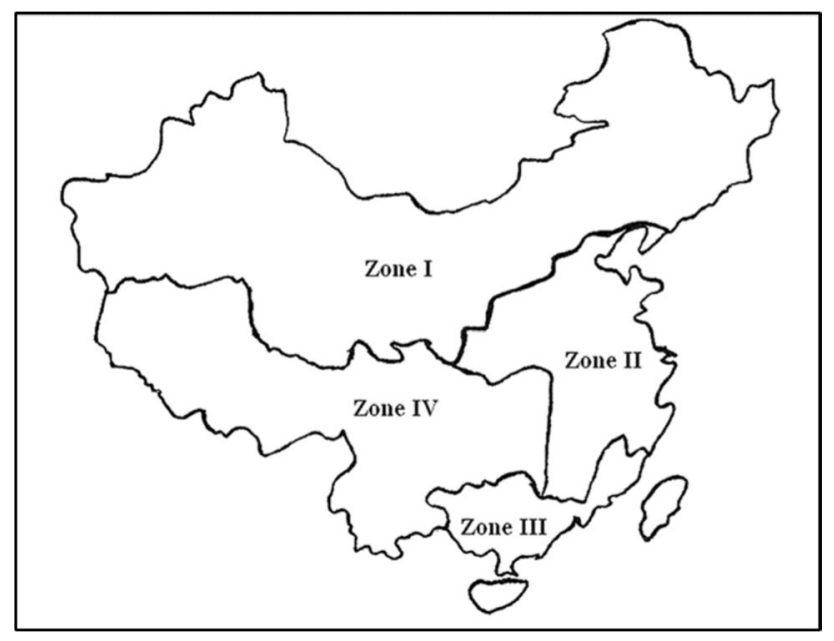

Map 1 Four major potato cultivation regions in China. Source Wang et al. 2011

developed very rapidly. These provinces underpin the predominant trend in southern China and provided the opportunity to compare the planting areas and typical agronomic norms between each region.

In recent years, Sichuan Province has ranked first in terms of potato area and output in China. Potatoes in Sichuan Province are planted at different altitudes and, consequently, divided into spring, fall and winter cropping zones. Although potato planting in Yunnan Province is like that of Sichuan Province, differences in latitude and altitude result in different planting times and cultivation practices. Finally, these three provinces have developed suitable local cultivation techniques for potato planting. Sustainable intensification has developed rapidly with the preferential support of national policies, and each has specific characteristics in the rice-potato rotation system.

Southern China is dominated by tropical and subtropical monsoon climates, with hot and rainy summers and mild winters with little rain. The annual precipitation is above $800 \mathrm{~mm}$, and the winter temperatures above 0 degrees centigrade. The terrain is complex and variable, including plains, hills, basins, and mountains. This area accounts for about $25 \%$ of the country's land area and about 2.4 million square kilometers. The potato cultivation system in China is roughly divided into four climatic regions (Map 1): the temperate north (Zone I), the Central Plains (Zone II), the winter cropping area (Zone III) of the south and the mixed cropping area (Zone IV) of the southwest which has the potential to adopt a rice-potato rotation pattern. The provinces under study are distributed across the southern winter cropping area and the southwest mixed cropping area.

\section{Results and Discussion}

\section{Paddy Rice-Upland Crop Rotation System in Selected Southern Provinces}

Through interviews with experts on potato cultivation and detailed reviews of available literature on paddy-dry rotations, the southern region contained approximately 16 million ha of fallow rice fields in winter. On one hand, the large number of fallow fields was because of rural labor shortages and high labor costs. On the other hand, because these paddy rice fields had a relatively poor soil water holding capacity, when fields were drained in preparation for dryland crops in the winter, due to low levels of organic matter and low temperatures, the soil may become hard with a poor condition unsuitable for planting. This unsuitability for multi-cropping is especially prevalent in the southwestern mixed cropping area (Zone IV), where mountainous terrain and small rainfed field sizes inhibit water management (i.e., irrigation and drainage) possible in other regions. Simultaneously, water resources are scarce in these provinces, irrigation is inadequate, and irrigation facilities are insufficient that is mainly a problem during the dry-cropping period (Wu and Jiang 2014). Winter is also a dry season in the south of China, low precipitation can lead to reduced potato yields, thus affecting farmers' income. At the same time, cost of water-saving irrigation facilities is very high because most winter potato is grown on small and scattered plots. These factors are limiting the development of rice and potato crop rotation system in winter crop areas (Wu and Jiang 2014). The current measures proposed by the Chinese government to transform low- and medium-yielding fields can only be achieved when the government invests in appropriate infrastructure, including water-saving irrigation systems.

The survey also found that the proportion of rice-potato rotations to the total proportion of potato acreage in each province differed significantly between the southern winter crop zone and the southwestern mixed crop zone. The proportion of winter potatoes planted in the southern winter crop area ranged from 88 to $100 \%$, while the proportion of winter potatoes planted in the southwestern mixed cropping area ranged from 4 to $40 \%$ (Table 4). The main reasons leading to this difference were the geography and climate variance between the winter crop area and the southwestern mixed crop area. The winter crop areas like Guangdong Province were mainly composed of hills, the annual rainfall being $1000-3000 \mathrm{~mm}$, and the frost-free duration being more than 300 days. These elements provide favorable conditions for planting potatoes in winter. The southwestern mixed crop area mainly consisted of mountains, so the temperature and rainfall were significantly different in low and high altitudes. 
Table 4 Potato cultivation in fallow paddy fields in some provinces in southern China in 2016

\begin{tabular}{|c|c|c|c|c|c|}
\hline Province & $\begin{array}{l}\text { Fallow rice land } \\
\left(10^{4} \mathrm{ha}\right)\end{array}$ & $\begin{array}{l}\text { Potato planting } \\
\text { area }\left(10^{4} \mathrm{ha}\right)\end{array}$ & $\begin{array}{l}\text { Potato planting area in the } \\
\text { rice fields }\left(10^{4} \mathrm{ha}\right)\end{array}$ & $\begin{array}{l}\text { Percentage of potato area } \\
\text { in the rice fields }\end{array}$ & $\begin{array}{l}\text { Percentage of potato area } \\
\text { planted in rice fields to total } \\
\text { potato area }\end{array}$ \\
\hline Zhejiang & 53.43 & 7.09 & 5.0 & $9.36 \%$ & $70.52 \%$ \\
\hline Anhui & 239.78 & 0.69 & - & - & - \\
\hline Fujian & 51.00 & 8.42 & 8.06 & $15.8 \%$ & $95.7 \%$ \\
\hline Jiangxi & 222.54 & 1.47 & 1.3 & $0.5 \%$ & $88.4 \%$ \\
\hline Hubei & 219.41 & 25.15 & - & - & - \\
\hline Hunan & 279.05 & 8.16 & - & - & - \\
\hline Guangdong & 95.19 & 4.66 & 4.66 & $4.8 \%$ & $100 \%$ \\
\hline Guangxi & 99.09 & 6.56 & 6.56 & $6.6 \%$ & $100 \%$ \\
\hline Chongqing & 65.89 & 37.18 & 6.7 & $10.2 \%$ & $18.0 \%$ \\
\hline Sichuan & 187.49 & 80.7 & 30.9 & $16.5 \%$ & $38.3 \%$ \\
\hline Guizhou & 70.05 & 73.17 & 15.2 & $9.56 \%$ & $9.16 \%$ \\
\hline Yunnan & 83.15 & 55.78 & 5.6 & $6.7 \%$ & $10.0 \%$ \\
\hline Total & 1666.08 & 309.03 & & & \\
\hline
\end{tabular}

(1) Fallow rice fields are the total of the middle-rice fields and late-rice fields, and rice fields data is sourced from the China Agriculture Statistical Report (2016); (2) Potato planting areas in the different province were investigated or were sourced from statistical data in 2016

Table 5 Conservation agriculture practice adopted in Yunnan, Sichuan and Guangdong

\begin{tabular}{|c|c|c|c|c|c|c|}
\hline \multirow[t]{2}{*}{ SI (sustainable intensification) practice } & \multicolumn{2}{|c|}{ Yunnan } & \multicolumn{2}{|c|}{ Sichuan } & \multicolumn{2}{|c|}{ Guangdong } \\
\hline & $+/-$ & $\begin{array}{l}\text { Adoption } \\
\text { rate of farm- } \\
\text { ers }\end{array}$ & $+/-$ & $\begin{array}{l}\text { Adoption } \\
\text { rate of farm- } \\
\text { ers }\end{array}$ & $+/-$ & $\begin{array}{l}\text { Adoption } \\
\text { rate of } \\
\text { farmers }\end{array}$ \\
\hline Integrated late blight management & + & $86 \%$ & + & $50 \%$ & + & $>90 \%$ \\
\hline Plastic film mulching & + & $43 \%$ & + & $50 \%$ & + & $>90 \%$ \\
\hline Water and fertilizer integration & + & $1.4 \%$ & - & $0 \%$ & - & $0 \%$ \\
\hline Mechanization & + & $57 \%$ & + & $10 \%$ & + & $>90 \%$ \\
\hline Soil testing and formula fertilization & + & No data & + & $50 \%$ & + & $80 \%$ \\
\hline Zero tillage & - & $0 \%$ & + & No data & - & $0 \%$ \\
\hline Drip irrigation & + & $1.4 \%$ & - & $0 \%$ & + & No data \\
\hline
\end{tabular}

$+:$ means to use these measures; - : means not to use
These conditions have a significant influence on crop planting in the southwestern mix crop area. For instance, Sichuan winter potatoes accounted for about $4 \%$. The low proportion was due to Sichuan Province being the country's largest winter rapeseed cultivation area and many rice fields being used for rapeseed cultivation (MOA 2020). Yunnan's proportion was high due to the economic benefits of winter potatoes being very high. For instance, in Dehong, Mangshi, Honghe, Jianshui and Kaiyuan in southern Yunnan, many farmers planted winter potatoes using the so-called "1-1-3-9 method". That is planting $1 \mathrm{mu}\left(45 \mathrm{t} / \mathrm{ha}^{-1}\right)$, for 100 days, with a yield of $3000 \mathrm{~kg}$ and an approximate revenue of CNY 9000 (USD 138.9)) (DARAYP 2018). Especially in Dehong, potato yields gradually increased to an average of $47 \mathrm{t} / \mathrm{ha}^{-1}$ (Li et al. 2019). Due to the better prices for potatoes than other winter crops such as tobacco, the farmer has more motivation to plant potatoes. Consequently, increases in winter potatoes in Yunnan Province have been swift, becoming the largest winter potato planting area in China (DARAYP 2018).

\section{Conservation Agriculture Practices in the Process of Rice-Potato Rotation}

As shown in Table 5, in the rice-potato rotation systems in the three provinces investigated, the leading conservation agricultural practice in potato planting included integrated late blight management, mechanization, plastic film mulching and soil testing and formula fertilization technology. The late blight integrated management is the principal measure taken in potato planting in southern China. It was found that farmers' adoption rate in Sichuan Province was 50\%, lower than Yunnan Province and Guangdong Province. The overriding reason was that farmers in Sichuan Province planted 
potato just for their own household consumption rather than to sell, so they did not spend much on integrated late blight management. The high adoption rate of potato as a winter crop in Guangdong and Yunnan was due to the 'farmers' reliance on agricultural revenues earned from the winter season. Intentions to maximize agricultural production obliged farmers to spend more on farm management and inputs. Plastic film mulching was the primary cultivation measure adopted for winter potato planting (Shan and Han 2015; Mo et al. 2017).

Table 5 also shows that the adoption rates of farmers in Yunnan and Sichuan were almost half of Guangdong. The reason for this difference was that regional geography (Zone IV) limited the use of the mechanization necessary for plastic-mulching. Likewise, the southwestern mix crop area's geography had the same impact on the adoption of mechanization. This impact was due to mountainous agroecology, leading to small disparate fields. Soil testing and formula fertilization was a quick and accurate method to determine the relative acidity of the soil $(\mathrm{pH})$ and the level of several essential nutrients (phosphorus, potassium, calcium, magnesium, sodium, sulfur, manganese, copper, and zinc) as a guide to farmer fertilization (Duan 2018; Bradley and Deanna. 2019). The Chinese Ministry of Agriculture has promoted the technology in recent years (Zhu et al. 2016), resulting in the increased adoption rate of technology by farmers. The practices of water and fertilizer integration and drip irrigation were barely present in the three provinces. It was understood that the irrigation facilities' cost was high and cumbersome for field-based production as evidenced by the expert's opinions. Also, recently high winter and spring rainfall in the southern regions resulted in farmers not adopting the practice. The zero-tillage technique was not practiced in Yunnan and Guangdong because paddy fields were not suitable for direct planting. Such practices resulted in tubers rotting before emergence.

\section{Benefit Analysis of the Rice-Potato Rotation System}

\section{Economic Benefit Analysis of the Rice-Potato Rotation}

The economic benefits of rice-potato rotation mainly referred to the increase in the rotation's production and profitability, closely related to farmers' incomes. This survey found that in contrast to the rice-fallow system, the rice-potato rotation system increased profitability by $266 \%$ (Table 6 ). Compared to the rice-fallow system, rice yields and thus outputs are lower in the rice-potato system. Despite the apparent loss in production, this phenomenon appeared to be due to the duration that a rice variety's crop takes to reach harvest. For instance, in the rice-potato rotation system, farmers plant the early maturing rice to ensure the required growth period for the succeeding potato crop, but in the rice-fallow system,
Table 6 Inputs, outputs, benefits and profitability in rice-potato and rice-fallow system

\begin{tabular}{|c|c|c|c|c|}
\hline \multirow[t]{2}{*}{ Item } & \multicolumn{2}{|c|}{ Rice-potato } & \multirow{2}{*}{$\begin{array}{l}\text { Rice-fallow } \\
\text { Rice }\end{array}$} & \multirow[t]{2}{*}{ Percentage } \\
\hline & Rice & Potato & & \\
\hline Yield $\left(\mathrm{kg} / \mathrm{ha}^{-1}\right)$ & 9000 & 33,000 & 11,250 & $273 \%$ \\
\hline Output $\left(\mathrm{CNY} / \mathrm{ha}^{-1}\right)$ & 22,500 & 75,000 & 27,000 & \\
\hline Input $\left(\mathrm{CNY} / \mathrm{ha}^{-1}\right)$ & 9000 & 22,500 & 9000 & \\
\hline Benefit $\left(\mathrm{CN} / \mathrm{ha}^{-1}\right)$ & 13,500 & 52,500 & 18,000 & $266 \%$ \\
\hline
\end{tabular}

a farmer can plant middle or late-maturing rice varieties resulting in greater rice yield. However, some early maturing rice varieties that fit into rice-potato systems may only result in a small yield reduction compared to medium or late maturing varieties (Hong et al., 2020). Transplanting rice, as practiced in the Indo-Gangetic Plains, could be another farming practice to maintain yields (Gatto et al., 2020). In this case, production increases compared to a scenario where the period after rice is left fallow.

Similarly, findings for intensified systems with potato have been documented by Qiu et al. (2015) who found that rice-potato rotations had higher economic benefits than the rice- rapeseeds rotation when analyzing the economic benefits. Unlike rice-rapeseed rotations, in rice-potato crop rotation systems, potato cultivation does not prevent earlier rice planting.

Li et al. (2016) also pointed out that under the "potatorice-rice" model in Guangdong Province, fertilization can be reduced by $80 \%$ compared to the control. After harvesting potatoes, early and late double-cropping rice are planted, allowing for a significant reduction in fertilization applications. Similar economic benefits were also observed in other parts of Asia where rice-potato systems are prominent (Gatto et al. 2020).

\section{Ecological Benefit Analysis of Rice-Potato Rotation From Reviewed Literature}

Intensification of agriculture results in higher input-use and, by default, negatively affects the environment, such as soil and water quality. However, input-use efficiency can be increased in rice-potato systems as both crops jointly require fewer inputs than both crops individually. The ecological benefits of rice and dry rotation refer to the impact on soil structure (Cui 2018), soil fertility (Liu and Jiang 2019), soil quality (Sun et al. 2019), the entire ecological environment and agricultural ecosystem after a particular farming system model is implemented or promoted (Wang et al. 2002; Liu and Jiang 2019). It is further implicated in the larger issue of sustainable development. Field experiments showed that paddy rice and dry rotation can improve the physical and chemical properties of the soil (Wang et al. 
2003), accelerate the renewal of organic matter, increase the permeability of the soil, and facilitate the effectiveness of soil nutrients. Yu (2010) analyzed the soil nutrients in the rice-potato rotation system. Yu's results showed that in this type of rotation system, after the potato is harvested, the quantity of organic matter, total nitrogen, total phosphorus, alkali hydrolyzed nitrogen, available phosphorus, and available potassium increased by $3.39 \mathrm{~g} / \mathrm{kg}^{-1}, 0.159 \mathrm{~g} /$ $\mathrm{kg}^{-1}, 0.029 \mathrm{~g} / \mathrm{kg}^{-1}, 15.2 \mathrm{mg} / \mathrm{kg}^{-1}, 17.2 \mathrm{mg} / \mathrm{kg}^{-1}, 42.6 \mathrm{mg} /$ $\mathrm{kg}^{-1}$ compared with rice-fallow. Wang et al. (2009) showed that the residues of the roots of different winter crops such as winter potatoes provide a relatively large amount of organic carbon source for the growth of microorganisms during rice growth and improved the activity of soil microorganisms. Zhang et al. (2009) also showed that different winter crops such as potato, ryegrass, milk vetch and rapeseed all increased the soil microbial activity, carbon and nitrogen content of paddy fields.

Wang et al. (2002) showed that the total weed coverage of the late rice field in the second year of the paddy and dry rotation was $80 \%$ less than that of the continuous late-rice field. Other studies also showed that aquatic and xerophytic weeds of the paddy-dry rotation, grass weeds such as oat grass in wheat fields and dodder seeds in the dry rotation with legumes had been effectively controlled. South China Agricultural University (2014) developed a method of planting potatoes in winter fallow rice fields that can effectively control the damage of Ampullaria gigas to early rice in the coming year. Xie et al. (2010) also indicated some soil and seed-borne diseases of potatoes in a rice-potato rotation, such as bacterial wilt, ring rot and scab disease (Wu et al. 2020), can be eliminated or significantly reduced after one or two rounds of flooding the paddy field. In summary, the rice-potato rotation can have positive ecological benefits within an agricultural ecosystem. Not only is the input-use efficiency increased, rotation contributes to improving soil health by increasing the utilization rate of the soil, thus reducing soil-borne diseases.

\section{Constraints of the Rice-Potato Rotation System in Southern China From Reviewed Literature}

In the rice-potato rotation system, several general factors affected rice-potato cultivation. First, despite the limited availability of arable land in China, urbanization continues to advance. A large amount of agricultural land has already been occupied. However, the total area of arable land in China was only 130 million ha, and the per capita arable land area was only 0.09 ha per person (Jiao 2018), the stability of agricultural production has been seriously affected. Among all the arable land in China, there are no restrictions on the necessary conditions for paddy and dry rotation. However, only $39 \%$ of the arable land with irrigation facilities was of relatively good quality. The remaining $60 \%$ of the arable land was affected by various restrictive factors. This nonarable land quality was relatively low, so these lands cannot be used for rice and dry crop rotation (Wu and Jiang 2014).

Another inhibitory factor was limited access to water resources. The major problem facing rice-potato rotation was water scarcity. $90 \%$ of water resources in Asia were used for agricultural production, and rice irrigation water accounted for $50 \%$ of the total agricultural water consumption (Bouman 2001). In China, nearly $70 \%$ of water resources were used for agricultural production, and rice irrigation accounted for $65 \%$ of total agricultural water consumption (Si et al. 2000). Winter was typically a dry season in the south of China, where rainfall was low, and rainfall cannot meet potato growth and development needs. Hence, irrigation was necessary to obtain high yields for potato tubers with a moisture content of about $75 \%$ to $80 \%$. Therefore, the water crisis was a critical factor restricting adoption of rice and dry crops' rotation (Wu and Jiang 2014).

Third, high-yielding and early maturing varieties that are also resistant to biotic and abiotic stressors were not readily available. In 2015 , between 15 and $20 \%$ of the area was planted to early/medium-maturing varieties (Gatto et al. 2018). Breeding for resistance/tolerance and earliness are key traits to make potatoes fit in rice-potato systems, to not affect spring sowing, and provide economic viability.

Fourth, the supplies of virus-free seed potatoes was one of the main restricting factors of the high yield of potatoes in the winter cropping areas. Most southern provinces in China have high temperatures and heavy rainfall in the summer. Virus vectors and sources of potato viruses are numerous and complex, which leads to rapid degradation of potato varieties and ultimately affects the yield and quality of commercial potatoes. Therefore, virus-free seed potatoes are generally transported from the north of China. However, recently, the high-altitude areas of the mixed cropping area of the southwest have also begun to produce virus-free seed potatoes, which means that seed potatoes grown in the winter cropping area may also be derived from the mixed cropping area.

Add to these factors the small land sizes and limited access to in- and output markets (Scott and Suarez 2012). While potato production may be more profitable compared with other crops, such as rapeseed, the mentioned factors, combined or individually, pose serious constraints to adoption of sustainably intensified rice-potato systems.

\section{Conclusions}

This article summarized the status and challenges of sustainable intensification of rice-potato rotation in southern China. It mainly analyzed the sustainable intensification method 
adopted in the rice-potato rotation system and the adoption rate of farmers in the selected provinces while analyzing the economic benefits under the rice-potato rotation mode. Using reviewed literature, the ecological benefits and constraints of rice-potato rotation were also analyzed.

The rice-potato rotation system was emphasized for higher economical profitability, which significantly motivated farmers to plant potatoes in winter. This article also showed that conservation agriculture practices have a diverse adoption rate among farmers across the three provinces. Generally, the adoption rate of farmers in Guangdong Province is much higher than in Yunnan Province and Sichuan Province. The significant reasons are due to the differences in geographic environment and climate. From the literature review, we found that rice-potato rotations can protect the environment and save agricultural production costs, enabling the agricultural production system to developing in a sustainable way. Due to the multiple advantages of potato planting and higher planting benefits, rice-potato rotation increased in the south of China.

However, some rice-potato rotation constraints included arable land, water resources, and access to quality seed potatoes. To solve the limitation of arable land and water resource, the Ministry of Agriculture of China issued the "Agricultural Resources and Ecological Environmental Protection Project Plan (2016-2020)" in 2017 (MOA 2017), proposing to transform low- and medium-yield fields, which was predicted to improve agricultural production conditions, the ecological environment, and increase land outputs. In southwestern regions such as Yunnan and Sichuan Province, the problem of seed potatoes has now begun to strengthen seed potato production capacity in middle and high altitude areas to provide high-quality seed potatoes for low altitude winter cropping areas.

This article presented a primary investigation into the merits of the rice-potato crop rotations to intensify production and potential revenues of farmers. Our sources of information relied on publicly available reports and individual interviews. To develop a more comprehensive picture of the three southern provinces, more interviews, field surveys, agronomic plot-level data, and household surveys are required.

This research has limitations. The primary data source used for this research were key informant interviews with a sample size of 30 . We acknowledge that the small number may lead to biased estimates of the rice-potato systems' potential. Including more experts, or using quantitative data collected through representative farmer samples accompanied by remote sensing data, is an important avenue of future research.

In conclusion, there are large areas of winter fallow fields in southern China that can be used to grow winter potatoes. While our study mainly focuses on the economic and agronomic potential of rice-potato systems in China, there are several constraints to production and uptake, as Scott and Suarez (2012) summarize: technical (such as poor quality seed and limited genetic base for breeding), natural (such as depleting water tables and higher temperatures exacerbated by climate change), institutional (such as land tenure and related small land sizes of about 1 ha constraining farmers to benefit from economies of scale). Providing an estimate of the potential area suitable for rice-potato cultivation that included those additional constraints would be worthwhile and an important area of future research.

Also, access to affordable quality seed and improved varieties that fit rice-potato systems will be important factors to make the cropping system successful. If successful, these measures can ensure the sustainable development of the rice-potato rotation system. As such, increasing potato planting in winter fallow rice fields can significantly contribute to China's food security and increase farmers' income in southern rice fields.

Supplementary Information The online version contains supplementary material available at https://doi.org/10.1007/s12230-021-09848-x.

Acknowledgements This research was undertaken as part of, and funded by, the CGIAR Research Program on Roots, Tubes and Bananas (RTB) and supported by CGIAR Trust Fund contributors. We wish to thank several researchers interviewed for this study for their information on rice-potato rotation and their data on conservation agriculture practices in southern China. We also want to thank the interviewers from Yunnan province, Guangdong province and Sichuan province who provided data of economic benefits of potato production. A special thanks goes to the team of AsiaBlight in CIP that gave information of integrated late blight management. We also want to thank Dr. Michael Kirch for his comments on an earlier draft of this paper.

Open Access This article is licensed under a Creative Commons Attribution 4.0 International License, which permits use, sharing, adaptation, distribution and reproduction in any medium or format, as long as you give appropriate credit to the original author(s) and the source, provide a link to the Creative Commons licence, and indicate if changes were made. The images or other third party material in this article are included in the article's Creative Commons licence, unless indicated otherwise in a credit line to the material. If material is not included in the article's Creative Commons licence and your intended use is not permitted by statutory regulation or exceeds the permitted use, you will need to obtain permission directly from the copyright holder. To view a copy of this licence, visit http://creativecommons.org/licenses/by/4.0/.

\section{References}

Bouman, B.A.M. 2001. Water-efficient management strategies in rice production. International Rice Research Notes 26: 2.

Bradley, L., and O. Deanna. 2019. A gardeners' guide to soil testing. https://content.ces.ncsu.edu/a-gardeners-guide-to-soil-testing

Chang, X., R.S. DeFries, L. Liu, and K. Davis. 2018. Understanding dietary and staple food transitions in China from multiple scales. PLoS ONE 13 (4): 0195775. 
Cui, Y. 2018. Research progress in paddy field rotation with water and drought (in Chinese). Crops 3: 8-14. https://doi.org/10.16035/j. issn.1001-7283.2018.03.002.

DARAYP. 2018. Create a green "cloud potato" to help promote poverty alleviation-writing a new chapter in rural revitalization in the new era (in Chinese). (Eds.) Potato industry and poverty alleviation, 12-17. Harbin: Harbin Cartographic Press.

Devaux, A., J.P. Goffart, A. Petsakos, P. Kromann, and G. Hareau. 2020. Global food security, contributions from sustainable potato agri-food systems. The Potato Crop. Springer, Cham. https://doi. org/10.1007/978-3-030-28683-5_1

Duan, Y. 2018. Research on soil testing and formula fertilization system based on wireless sensor network. (eds.) Proceedings of 2018 2nd international conference on computer science and intelligent communication (CSIC 2018), 318-324.

Food and Agriculture Organization of the United Nations. 2021. FAOSTAT statistical database. Accessed June 2021.

Fu, Z., Y. Cai, Y. Yang, and E. Dai. 2001. Correlation analysis of China's food security and arable land resource changes (in Chinese). Journal of Natural Resources 04: 313-319. https://doi. org/10.3321/j.issn:1000-3037.2001.04.003.

Garibaldi, L. A., B. Gemmill-Herren, R. D'Annolfo, B.E. Graeub, S.A. Cunningham, and T.D. Breeze. 2017. Farming approaches for greater biodiversity, livelihoods, and food security. Trends in Ecology \& Evolution 32 (1): 68-80. ISSN 0169-5347

Garnett, T., M.C. Appleby, A. Balmford, et al. 2013. Sustainable intensification in agriculture: Premises and policies. Science 341 (6141): 33-34.

Gatto, M., A. Petsakos, and G. Hareau. 2020. Sustainable intensification of rice-based systems with potato in Eastern Indo-Gangetic Plains. American Journal of Potato Research 97: 162-174. https://doi.org/10.1007/s12230-020-09764-6.

Gatto, M., G. Hareau, W. Pradel, V. Suarez, and J. Qin. 2018. Release and adoption of improved potato varieties in Southeast and South Asia. International Potato Center (CIP) Lima, Peru. ISBN 978-92-9060-501-0. 42p. Social Sciences Working Paper No. 2018-2.

He, W., W. Wu, Q. Yu, W. Hu, J. Tan, and Y. Hu. 2016. From 1980 to 2010, multiple cropping of cultivated land in China can increase the potential spatial pattern changes (in Chinese). China Agricultural Resources and Regionalization 11: 7-14.

Hong, J., R. Fan, and X. Bai. 2020. Honghe prefecture "Rice-Potato" green and high efficient paddy-upland rotation model (in Chinese). Yunnan Agricultural Science and Technology 03: 29-31.

Huang, G. 2009. Ten problems facing the sustainable development of the rice farming system in southern China (in Chinese). Farming and Cultivation 03: 1-2.

Huang, G. 2017. Problems and countermeasures in the sustainable development of agricultural ecosystems in southern China (in Chinese). Chinese Journal of Eco-Agriculture 01: 13-18. https:// doi.org/10.13930/j.cnki.cjea.160658.

Jia, X., Z. Wang, B. Zhang, C. Su, W. Du, J. Zhang, H. Jiang, F. Huang, Y. Ouyang, Y. Wang, L. Li, and H. Wang. 2020. Changes in the awareness of nutritional knowledge in Chinese adults during 2004-2015 (in Chinese). Journal of Hygiene Research 49 (03): $345-356$

Jiang, M., X. Li, L. Xin, and M. Tan. 2019. Paddy rice multiple cropping index changes in Southern China: Impacts on national grain production capacity and policy implications (English). Journal of Geographical Sciences 11: 1773-1787. https://doi.org/10.1007/ s11442-019-1689-8.

Jiao, S. 2018. 2017 China land, mineral and marine resources statistical bulletin released (in Chinese). Resources Guide 329 (06): 36-36.

Jin, L., D. Qu, K. Xie, C. Bian, and S. Duan. 2003. Research progress on potato germplasm resources and breeding technology in my country (in Chinese). Seed 05: 98-100. https://doi.org/10.16590/j. cnki.1001-4705.2003.05.100.

Lenaerts, B., B. Collard, and M. Demont. 2019. Review: Improving global food security through accelerated plant breeding. Plant Science: An International Journal of Experimental Plant Biology 287: 110207. https://doi.org/10.1016/j.plantsci.2019.110207.

Li, C., C. Guan, J. Cheng, and P. Vanderzaag. 2019. Intensive potato production by farmers in DeHong, China. American Journal of Potato Research 96: 610-613. https://doi.org/10.1007/ s12230-019-09744-5.

Li, X., X. Liu, Y. Lai, H. Suo, L. Wang, and K. An. 2016. Study on fertilization reduction of double-cropping rice under the "potatorice-rice" rotation mode (in Chinese). Chinese Journal of Tropical Crops 10: 1877-1881.

Li, C., J. Lv, X. Wang, X. Li, Y. Li, and Q. Xie. 2004. Research progress and application of modern agricultural ecology (in Chinese). Journal of Henan University of Science and Technology (agronomy Edition) 03: 72-75.

Lichtenberg, E., and C. Ding. 2008. Assessing farmland protection policy in china. Land Use Policy 25 (1): 59-68.

Liu, X. 2000. On the intensification and sustainability of Chinese agriculture (in Chinese). Agricultural Modernization Research 01: $1-8$.

Liu, X., and T. Ren. 1993. Intensive and sustainable agriculture-the main choice between China and developing countries (in Chinese). World Agriculture 09: 4-6.

Liu, Y., and Z. Jiang. 2019. Research progress and development suggestions on the ecological effects of paddy-upland rotation in rice fields (in Chinese). Jiangsu Agricultural Sciences 47 (20): 19-23.

Long, W., D. Zhang, S. Li, and J. Peng. 2018. Empirical analysis of the competitiveness of China's potato industry. World Agriculture 472 (08): 191-198.

Lu, D., Y. Wang, Q. Yang, H. He, and K. Su. 2019. Exploring a moderate fallow scale of cultivated land in China from the perspective of food security. International Journal of Environmental Research and Public Health 16 (22): 4329.

Luo, Q. 2015. Economic research on potato industry (in Chinese), vol. 9, 1. Beijing: China Agriculture Press.

Matson, P.A., W.J. Parton, A.G. Power, and M.J. Swift. 1997. Agricultural intensification and ecosystem properties. Science (new York, N.y.) 277 (5325): 504-509.

Mo, Q., D. Wu, J. Lu, X. Li, S. Gong, Y. Zhou, Y. Yue, and S. Lu. 2017. Preliminary study on the cultivation technology of winter potato with film mulching (in Chinese). Cultivation and Cultivation (02): 12-14+11. https://doi.org/10.13605/j.cnki.52-1065/s. 2017.02.005.

MOA. 2016. Guiding opinions of the ministry of agriculture on promoting the development of the potato industry (full text) [EB/ OL]. http://www.moa.gov.cn/nybgb/2016/disanqi/201711/t2017 1126_5919565.htm.

MOA. 2017. Agricultural resources and ecological environmental protection project plan (2016-2020) [EB/OL]. http://www.moa.gov. cn/nybgb/2017/dyiq/201712/t20171227_6129936.htm.

MOA. 2020. The rapeseed planting area in Sichuan reaches 19 million $\mathrm{mu}$. Rapeseed production is expected to increase by 19 consecutive years this year [EB/OL]. http://www.moa.gov.cn/xw/qg/ 202004/t20200417_6341823.htm.

Myrick, S., W. Pradel, C. Li, V. Suarez, and J. Alwang. 2021. The curious case of C-88: Impacts of a potato variety on farmers in Yunnan, China. CABI Agriculture and Bioscience 2: 3. https://doi. org/10.1186/s43170-020-00022-7.

NBSPRC (National Bureau of Statistics of China). 2017. China statistical yearbook. Beijing: China Statistics Press.

Ni, W. 2018. Sustainable intensification leads the development of modern agriculture (in Chinese). Science News 12: 75-77. 
Qiu, X., X. Li, D. Zhang, and S. Lu. 2015. High-yield and high-efficiency technology of potato stubble in the hilly area of Sichuan Basin and the benefit analysis of farming system changes (in Chinese). Sichuan Agricultural Science and Technology 08: 20-22.

Qu, D., K. Xie, L. Jin, W. Pang, C. Bian, and S. Duan. 2005. China's potato industry development and food safety (in Chinese). Chinese Agricultural Sciences 38 (2): 358-362.

Rockstrom, J., J. Williams, G. Daily, et al. 2017. Sustainable intensification of agriculture for human prosperity and global sustainability. Ambio 46 (1): 4-17.

Scott, G.J., and V. Suarea. 2012. From Mao to McDonald's: Emergencing markets for potatoes and potato products in China 1961-2007. American Journal of Potato Research 89 (3): 216-231.

Scott, G., and V. Suarez. 2012. Limits to growth or growth to the limits? Trends and prospects for potatoes in China and their implications for industry. Potato Research 55 (2): 135-156. https://doi. org/10.1007/s11540-012.9215-8.

Scott, G. 2020. A review of root, tuber and banana crops in developing countries: Past, present and future. International Journal of Food Science and Technology. https://doi.org/10.1111/ijfs.14778.

Shan, L., and B. Han. 2015. Research and extension process and existing problems of biodegradable agricultural mulch film at home and abroad (in Chinese). Shaanxi Agricultural Sciences 12: 73-77.

Shen, J., F. Zhang, and Kadambot H. M. Siddique. 2018. Sustainable resource use of in enhancing agricultural development in China. Engineering 4 (05): 21-24.

Si, T., H. Wang, and W. Zhang. 2000. Discussions and suggestions on several issues of water saving in rice in China (in Chinese). Journal of Irrigation and Drainage 19 (001): 30-33. https://doi. org/10.13522/j.cnki.ggps.2000.01.009.

South China Agricultural University. 2014. A method of using wintergrowing potatoes in winter fallow rice fields to control snails (in Chinese): CN201410269308.6. 2014-08-27.

Sun, H., M. Sun, S. Lu, Z. Li, and Y. Zhang. 2019. The effect of paddy and dry rotation on soil and rice (in Chinese). Heilongjiang Agricultural Sciences 10: 141-143.

Tilman, D., C. Balzer, J. Hill, and L. Belinda. 2011. Global food demand and the sustainable intensification of agriculture. PNAS 108 (50): 20260-20264.

Tong, P. 1998. Development of multi-cropping and construction of high-yielding farmland-views and suggestions on sustainable increase of grain production. Farming \& Cultivation (05): 1-2+6.

Wang, B., Y. Ma, Z. Zhang, Z. Wu, Y. Wu, Q. Wang, and M. Li. 2011. Potato viruses in china. Crop Protection 30 (9): 1117-1123.

Wang, L., and J. Wang. 2004. The unification of the study of global change and the territorial system of man-land relationship (in Chinese). Tropical Geography 024 (004): 301-305.

Wang, L., Z. Zeng, G. Yang, X. Xiao, F. Zhang, and Y. Hu. 2009. Effects of winter crops on soil microbial biomass carbon and nitrogen during rice growth period (in Chinese). Journal of Plant Nutrition and Fertilizer 015 (002): 381-385.

Wang, R., X. Li, M. Tan, L. Xin, X. Wang, Y. Wang, and M. Jiang. 2018. Inter-provincial differences in rice multi-cropping changes in main double-cropping rice area in china: Evidence from provinces and households. Chinese Geographical Science 29: 127138. https://doi.org/10.1007/s11769-018-0972-4.

Wang, S., G. Huang, N. Li, and L. Liu. 2002. Soil microbial effects of paddy-upland rotation (the third year) (in Chinese). Journal of Jiangxi Agricultural University 03: 320-323.
Wang, Y., Y. Huai, and J. Xu. 2019. Ecological effect analysis of the "rice +" green and efficient model (in Chinese). Chinese Agricultural Science Bulletin 35 (27): 12-16.

Wang, Z., M. Gao, J. Qin, and E. Ci. 2003. The effect of long-term paddy and dry rotation of rice fields on soil fertility (in Chinese). Journal of Southwest Agricultural University (natural Science Edition) 25 (6): 514-517.

Wen, M. 2015. Measures and methods for increasing multiple cropping index of dryland crops in Guang' an (in Chinese). Rural Economy and Science and Technology 01: 62-63.

Wu, C., X. Liu, W. Zhang, Q. Wang, and H. Guo. 2020. The effects of different potato varieties (lines) and rice and potato rotation patterns on root-knot nematode disease (in Chinese). Acta Agronomica Sinica 09: 1456-1463.

Wu, Y., and K. Jiang. 2014. Analysis on the sustainable development of paddy-upland rotation model (in Chinese). Zhejiang Agricultural Sciences 06: 813-815. https://doi.org/10.16178/j.issn.0528-9017. 2014.06.011.

Xiang, J., and Y. Tang. 2005. Intensive agriculture and its environmental effects (in Chinese). World Science and Technology Research and Development 06: 81-87. https://doi.org/10.16507/j.issn.10066055.2005.06.014.

Xie, H., and Y. Yang. 2020. A review of international viewpoints on China's food security. World SCI-TECH R\&d 06: 633-645. https:// doi.org/10.16507/j.issn.1006-6055.2020.06.008.

Xie, K., X. Wang, and F. Wang. 2010. Potato production potential and problems in winter fallow rice fields in my country (in Chinese). China Potato 24 (006): 370-375. https://doi.org/10.3969/j.issn. 1672-3635.2010.06.015.

Yan, M., Y. Liu., and M. Cao. 2005. Spatial and temporal changes of cultivated land replanting index in China in the past 20 years. Acta Genographica Sinica (04): 33-40. https://doi.org/CNKI: SUN:DLXB.0.2005-04-005

Yang, Z., Q. Yu, and H. Liu. 2017. Potato industry situation in recent years and 2017 outlook (in Chinese). Agricultural Outlook (9).

Yu, H. 2010. The effect of planting potatoes in winter fallow fields on the soil environment of subsequent crops and rice growth (Master's thesis, Hunan Agricultural University) (in Chinese). https:// kns.cnki.net/KCMS/detail/detail.aspx?dbname $=$ CMFD2011an dfilename $=2010226495$. nh.

Yu, H., P. Sun, G. Yu, and X. Liu. 1999. On the theoretical development of China's intensive and sustainable agriculture. Journal of Shenyang Agricultural University (in Chinese). Social Science Edition 03: 3-5.

Zhang, F., F. Huang, X. Xiao, and J. Wu. 2009. Short-term effects of winter crops on rice soil microbial biomass carbon, nitrogen and microbial entropy (in Chinese). Acta Ecologica Sinica 02: 186-191.

Zhang, X., and D. Hu. 2014. Overcoming successive bottlenecks: The evolution of a potato cluster in China. World Development 63: 102-112. https://doi.org/10.1016/j.worlddev.2013.10.003.

Zhu, Z., P. Huang, and Y. Huang. 2016. Interpretation of the national standard GB/T31732-2015 "Soil testing and formula fertilizationtechnical specifications for fertilizer service points" (in Chinese). Standard Science 04: 74-77. 